\title{
Article
}

\section{Freedom of Religion: Lifting the Veils of Power and Prejudice}

\author{
Alkiviadou, Natalie \\ Available at http://clok.uclan.ac.uk/29325/ \\ Alkiviadou, Natalie ORCID: 0000-0002-4159-8710 (2020) Freedom of Religion: \\ Lifting the Veils of Power and Prejudice. The International Journal of Human \\ Rights, 24 (5). pp. 509-530. ISSN 1364-2987
}

It is advisable to refer to the publisher's version if you intend to cite from the work. http://dx.doi.org/10.1080/13642987.2019.1648260

For more information about UCLan's research in this area go to http://www.uclan.ac.uk/researchgroups/ and search for < name of research Group>.

For information about Research generally at UCLan please go to http://www.uclan.ac.uk/research/

All outputs in CLoK are protected by Intellectual Property Rights law, including Copyright law. Copyright, IPR and Moral Rights for the works on this site are retained by the individual authors and/or other copyright owners. Terms and conditions for use of this material are defined in the policies page.

\section{CLoK}

Central Lancashire online Knowledge www.clok.uclan.ac.uk

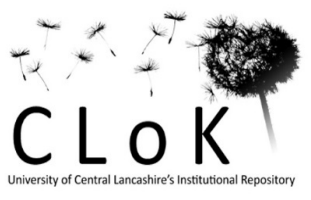


Freedom of Religion: Lifting the Veils of Power and Prejudice.

Dr. Natalie Alkiviadou, Lecturer in European Union Law and Human Rights, University of Central Lancashire Cyprus 


\title{
Key words
}

Human rights, freedom of religion, European Court of Human Rights, Court of Justice of the European Union

\begin{abstract}
$\underline{\text { Abstract }}$
This paper brings together case-law of the European Court of Human Rights and the Court of Justice of the European Union, for purposes of assessing the extent to which pluralism underpins decisions involving religious manifestation in the form of the Christian cross, on the one hand, and the Islamic veil on the other. The discussion of the jurisprudence reflects that the two Courts have not set adequate benchmarks of protection for religious minorities and have not conceptualised themselves as key players to fight the growing Islamoprejudice marking a plethora of European realms. Instead, they have either reiterated negative narratives or hidden behind the acceptable shield of neutrality.
\end{abstract}




\section{Introduction}

Freedom of religion is protected by documents, such as the International Covenant on Civil and Political Rights and the European Convention on Human Rights (ECHR), as well as national constitutions. According to the European Court of Human Rights (ECtHR), it is 'one of the most vital elements that go to make up the identity of believers and their conception of life, but it is also a precious asset for atheists, agnostics, sceptics and the unconcerned.' ${ }^{1}$ Article 9 of the ECHR provides that the manifestation of this right is subject to limitations, insofar as these are legitimate and necessary in the interests of public safety, for the protection of public order, health and/or morals and/or for the protection of the rights and freedoms of others. In other words, any externalisation of this freedom is not absolute and, as will be demonstrated hereinafter, its limitation is dependent upon the State, with the ECtHR theoretically exercising European supervision. ${ }^{2}$ On a European Union level, the Charter of Fundamental Rights reaffirms the rights enshrined in the ECHR and the case-law of the ECtHR as well as setting out the freedom of religion in Article 10. Furthermore, Council Directive 2000/78/EC establishes a general framework for combatting discrimination on the grounds of, inter alia, religion or belief as regards employment and occupation, with a view to putting into effect the principle of equal treatment in the Member States. In order to ascertain whether we are all, in fact, equal under the eye of the freedom in question and within the EU's non-discrimination framework, this paper will examine the extent to which European judicial practice, namely the jurisprudence of the ECtHR and the Court of Justice of the European Union (CJEU), protects religion and upholds the repeated and significant observance of Strasbourg that 'the pluralism indissociable from a democratic society, which has been clearly won over the centuries, depends on it. ${ }^{3}$ More particularly, through a comparative analysis of major decisions of the abovementioned courts, involving the manifestation of the Christian and Islamic religions in the form of symbols and clothing, this paper will assess whether pluralism has, in fact, been achieved. The choice of the two particular religions is necessary for the central argument of the paper, namely, that the

\footnotetext{
${ }^{1}$ See, inter alia, Kokkinakis v. Greece, App. No 14307/88 (ECHR 25 May 1993) para. 31

${ }^{2}$ Ibid. para. 47

${ }^{3}$ Ibid. para. 31
} 
Islamoprejudice $^{4}$ which mars the European reality, on the one hand, and the power of the majority, on the other, have infiltrated both of the Courts' theological (!) conceptualisation of themes such as the manifestation of a religion and the resulting judgments. The damning effect of this reality is that, once again, some (members of the majority) are just more equal than others (members of the minority) when it comes to exercising human rights, in this case, the freedom of religion.

\section{Jurisprudence of the ECtHR: A case of double standards?}

This section will provide an analysis of case-law of the European Court of Human Rights which has dealt with the 'manifestation' of the Islamic and Christian religions in the form of the hijab, niqab and burqa, on the one hand, and the crucifix on the other. The main argument put forward is that, notwithstanding the recognition by the ECtHR that freedom of religion constitutes a central tenet of pluralism, the Court itself has not been pluralist in its approach to freedom of religion cases involving Islam. In this respect, seven cases are particularly relevant and will be discussed hereinafter. In relation to Islam, these are Dahlab v Switzerland (concerning a primary school teacher who was prohibited from wearing her hijab at work), Leyla Șahin $v$ Turkey (involving the prohibition of hijabs on university premises) and S.A.S v France, Belkacemi and Oussar v. Belgium and Dakir v Belgium (regarding the French and Belgian blanket bans on wearing full face veils in public spaces). For Christianity, the cases that will be considered are Eweida and Others $v$ The United Kingdom and Lautsi and Others $v$ Italy, both involving the Christian crucifix.

\subsection{Dahlab v Switzerland}

Dahlab $v$ Switzerland involved the dismissal of the applicant from her position as a school teacher in a State primary school because she was wearing a hijab at work. The national court found that this did constitute an interference with her freedom of religion but that it was justified by the democratic need to protect the right of pupils to be taught in a secular environment and also found the wearing of the hijab to run contrary to gender equality. ${ }^{5}$ The ECtHR agreed that

\footnotetext{
${ }^{4}$ For a discussing of the term 'Islamoprejudice' and a variation to the term 'Islamophobia' look at: Roland Imhoff \& Julia Recker 'Differentiating Islamophobia: Introducing a New Scale to Measure Islamoprejudice and Secular Islam Critique' (2012) 33 Political Psychology 6

${ }^{5}$ Dahlab v. Switzerland, App. No 42393/98 (ECHR 15 February 2011)
} 
the interference was justified but focused on the negative effects of the hijab on young pupils rather than conducting a normative analysis of the relationship between the wearing of the hijab and secularism, which was the central justification for interference put forward by the national court, while leaving out any trace of a real impact test of Dahlab's headscarf on secularism.

It must be noted that the ECtHR started off promisingly in the sense that it made a contextual appraisal of the case, noting that Dahlab had worn the hijab for three years before being dismissed from work and that during that time no action had been taken by the school and no comments had been made by parents. During that time, there were 'no objections to the content or quality of the teaching provided by the applicant ${ }^{6}$ nor was there any indication that the applicant had 'sought to gain any kind of advantage from the outward manifestation of her religious beliefs.' 7 These two indicators denoted that (i) the applicant continued to perform her teaching duties to the relevant standard notwithstanding her hijab and (ii) she did not try to proselytise the children with/through/notwithstanding her hijab. Although the ECtHR started its reasoning with substance and context, the findings of which are contrary to the final decision, the rest of its approach did not follow this fact-finding and real impact route but, rather, listed a set of generalised and unfounded suppositions. In reaching its decision, the Court looked at the 'tender' age of the applicant's pupils and the hijab as a 'powerful external symbol' capable of having a 'proselytising effect' on the young pupils. It did not, however, substantiate on the nexus between age and proselytism, instead admitting that it was difficult to assess the impact of the hijab on young children, but continued to use their 'tender age' as a central element of its findings. The court did not extrapolate on its description of the hijab as something powerful and it completely disregarded its finding that no complaints had been made against the teacher during the three years she had been teaching on the grounds of proselytism. Its unsubstantiated findings did not stop there and continued into the field of stereotypes and, some (including myself) would argue, prejudice. More particularly, it noted that it:

6 Ibid.

7 Ibid. 
'appears difficult to reconcile the wearing of an Islamic headscarf with the message of tolerance, respect for others and, above all, equality and non-discrimination that all teachers in a democratic society must convey to their pupils. ${ }^{8}$

Further, the Court underlined its concern for the proselytising effect of the hijab since it 'appears to be imposed on women by a precept which is laid down in the Koran and which, as the federal court noted, is hard to square with the principle of gender equality. ${ }^{9}$ The Court does not say why, how and to whom it appears to be imposed on women and does not explain the link between its concerns about proselytism, the fact that the wearing of the veil is laid down in the Koran and its own perception of gender inequality.

Interestingly, in S.A.S, which involved the burqa ban and is discussed further down, it was underlined that:

'as the Court has previously noted, these three values (respect for equality between men and women, respect for human dignity and respect for the minimum requirements of life in society) do not expressly correspond to any of the legitimate aims enumerated in the second paragraphs of Articles 8 and 9 of the Convention.'

Although the ECtHR held that it had previously underlined that these values do not correspond to any of the legitimate aims (without citing or referring to when and where it said this), it is indisputable that concerns over gender equality have shaped, at least in part, (a big part), the reasoning of the Courts in Dahlab and in the case of Şahin below. The difference with S.A.S is that values, such as gender equality, have essentially been 'replaced' by the new doctrine of 'living together' extrapolated on later on.

\subsection{Leyla Şahin v Turkey}

The case of Leyla Shahin v Turkey involved the wearing of a hijab by a student on university premises. Şahin was a fifth year medical student when Istanbul University distributed a circular

\footnotetext{
${ }^{8}$ Ibid.

${ }^{9}$ Ibid.
} 
banning beards and headscarves in lectures and examinations. The applicant refused to remove her headscarf and was prevented from entering lectures and examinations. As with Dahlab, the Court's reasoning was troublesome. It found that the restriction of Article 9 was justified in order to protect secularism which the Court noted was the 'paramount consideration' ${ }^{10}$ underlying the ban, but was also necessary in order to prevent extremism on campus and protect values that the wearing of the hijab was perceived as difficult to reconcile with, for example, gender equality and tolerance. In reaching its decision, it spoke, once again, of the importance of pluralism and noted that 'the role of authorities in such circumstances is not to remove the cause of tension by eliminating pluralism but to ensure that the competing groups tolerate each other.' ${ }^{11}$ This is precisely the spirit of pluralism and a functioning democracy. However, the Court's judgment went contrary to its own statement since, by allowing the removal of the hijab, without any adequate justification, as will be explained below, it did not practise what it preached. Instead, it removed the perceived cause of tension which was, in this case, the headscarf. As well as recognising the significance of pluralism in a democratic society (but not adhering to its own observation), the Court also recognised, as with all Article 9 cases, that religious freedom is 'one of the most vital elements that go to make up the identity of believers and their conception of life' ${ }^{12}$ However, once again, these statements were fragile and almost hypocritical. The ECtHR recognised and adhered to the notion of secularism put forth by the national court but did so through an almost absolute reliance on the judgment of the Turkish court as well as a set of generalised assessments, without an adequate and contextualised investigation into the particular facts of this case. In relation to the doctrines put forward by the Court as justifications of the ban, namely secularism, equality and liberty, as aptly noted by Judge Tulkens, it 'is necessary to seek to harmonise [them] not to weigh one against the other.' ${ }^{13}$ Unfortunately, the Court, when dealing with the hijab, adopts a segregationist approach both in terms of how it conceptualises secularism and neutrality when discussing religion and also how it conducts an 'us' (liberal democratic values) v. 'them' (practices founded on religious dogma which are by default in contravention to these values) approach to the hijab. To make matters worse, it conducts this exercise without proper normative and contextual assessment of the matters at stake. As noted by

\footnotetext{
${ }^{10}$ Leyla Şahin v. Turkey, App. No. 44774/98 (ECHR 10 November 2005) para.116

${ }^{11}$ Ibid. para.107

${ }^{12}$ Ibid. para.104

${ }^{13}$ Ibid. para. 4
} 
Judge Tulkens, 'only indisputable facts and reasons...not mere worries or fears ${ }^{14}$ can justify interference with a Convention right. This should be further reinforced if the aforementioned observations of the Court regarding the paramount importance that Article 9 has in the life of a religious individual and for a pluralist democracy, more generally, are to be upheld.

The above described generalisation, thus, meant that there was no substantial examination of the nexus between secularism and the hijab, nor was there any adequate analysis of the applicant's status as a student of higher education rather than, as in Dahlab, a teacher. On this note, Tulkens argues that no manifestation of religion is to be compulsory for teachers and public servants as although 'they have voluntarily taken up posts in a neutral environment, the position of pupils and students seems to me to be different.' ${ }^{15}$ Although I agree with the bulk of Tulkens' dissenting argument, this point is open to dispute and that dispute goes back to definitional and semantical basics: what is secularism? In a paper on the CJEU's decision in Achbita, Weilers noted the following:

'Imagine three universities. In one, and I am familiar with such institutions, everyone, students and teachers, has to wear a yarmulke and a scarf. In another, no one is allowed to display any symbol manifesting their religious allegiance. In the third, everyone is free to follow their conscience. Some wear crosses, hijabs and turbans, others do not, but may sport buttons or shirts displaying vegan or Marxist or other signs manifesting their secular commitments, or they may wear no signs at all. If Major Tom were to find these institutions on Mars and send a report back to Ground Control, would he not report that the first two universities were not neutral, one had odiously enforced religiosity, the other (odiously?) enforced laïcité, and that only the third was neutral? At least food for thought., 16

So, maybe what the Court could benefit from is an in-depth consideration of the meaning and substance of values, doctrines and principles before citing and relying on them for purposes of restricting Convention rights. If such an exercise were conducted, there would be no need to

\footnotetext{
14 Ibid. para.5

15 Ibid. para. 7

${ }^{16}$ Joseph H.H. Weiler, 'Case Comment: Je Suis Achbita' (2017) 28 European Journal of International Law 4, 1003
} 
adopt the aforementioned segregationist approach to values and practices which are unfoundedly perceived as competing. The over-reliance on the Turkish Constitutional Court's decision was not only in contravention of the Court's duties as protector of the ECHR, but also constituted a comfort zone for the majority of its judges who simply did not (want to) embark on the necessary normative and contextual investigation. Either way, the impact of the Court's approach is that 'the Court did not judge Sahin's claims but rather the challenge of Islamic movements to the secular system.' 17

In addition to this, and as well as being stifled by generalisations and stereotypes regarding gender equality and extremism, the judgment never investigated the alleged (by the government and the national Court) tension caused by the hijab on university premises and the real circumstances of the issue, even when faced with the radical measure of a blanket ban on hijabs on campus. In relation to extremism, the Grand Chamber embraced the Chamber's position that:

'the Court does not lose sight of the fact that there are extremist political movements in Turkey which seek to impose on society as a whole their religious symbols and conception of a society founded on religious precepts ... It has previously said that each Contracting State may, in accordance with the Convention provisions, take a stance against such political movements, based on its historical experience (see Refah Partisi - the Welfare Party). The regulations concerned have to be viewed in that context and constitute a measure intended to achieve the legitimate aims referred to above and thereby to preserve pluralism in the university.' 18

However, there was no contextual investigation as to the impact of the hijab on the mobilisation and/or rise and/or activity of extremist movements on campus. The applicant argued that there had been 'no sign of tension in institutions of higher education that would have justified such a radical measure.' ${ }^{19}$ Even this statement did not prompt the Court to investigate the context.

\footnotetext{
${ }^{17}$ Kerem Altiparmak \& Onur Karahanogullari, 'Case Note: After Sahin: The Debate on Headscarves is Not Over, Leyla Sahin v. Turkey, Grand Chamber Judgment of 10 November 2005, Application No. 44774/98' (2006) 2 European Constitutional Law Review 2, 272

${ }^{18}$ Leyla Şahin v. Turkey, App. No 44774/98 (ECHR 10 November 2005) para.115

${ }^{19}$ Ibid. para.100
} 
Instead, it evaded such considerations, residing, instead, in unfounded generalisations. As a result, as simple and as worrying as it may be:

'it is very difficult, if not impossible, to understand how the court reconciled the headscarf with the measures employed. It never assessed whether the applicant's move constituted a threat to the public order in the Istanbul university. ${ }^{20}$

For example, was there any proof that wearing the hijab on campus led to a rise in fundamentalist movements? Was there any proof that the applicant was a member of a fundamentalist movement? Moreover, did the Court not fear, even a little bit, that it was moving in the space of generalisations or outright Islamoprejudice given the unsubstantiated nexus embraced between the wearing of the hijab in Turkey and fundamentalists? To make matters worse and the judgment less convincing, the Court relied on Refah Partisi for jurisprudential reinforcement, a case involving an entire political party calling for the application of Islamic Law in Turkey. How the Court qualitatively and quantitatively considered the particular finding in that case relevant for justifying the restriction of the wearing of a hijab by a student is, to say the least, unclear.

In relation to gender equality and women's choice vis-à-vis the headscarf, the Grand Chamber embraced the position of the Chamber which embraced the position of the Turkish Constitutional Court that:

'...like the Constitutional Court ..., the Court considers that, when examining the question of the Islamic headscarf in the Turkish context, it must be borne in mind the impact which wearing such a symbol, which is presented or perceived as a compulsory religious duty, may have on those who choose not to wear it. As has already been noted [in Karaduman and Refah Partisi (the Welfare Party) and Others], the issues at stake include the protection of the 'rights and freedoms of others' and the 'maintenance of public order' in a country in which

\footnotetext{
${ }^{20}$ Kerem Altiparmak \& Onur Karahanogullari, 'Case Note: After Sahin: The Debate on Headscarves is Not Over, Leyla Sahin v. Turkey, Grand Chamber Judgment of 10 November 2005, Application No. 44774/98' (2006) 2 European Constitutional Law Review 2, 281
} 
the majority of the population, while professing a strong attachment to the rights of women and a secular way of life, adhere to the Islamic faith., ${ }^{21}$

However, it does not examine or extrapolate on how the applicant's wearing of a headscarf impacted others who did not want to wear it and relied, once again, on Refah Partisi, confusing the readers of this judgment regarding the link between an entire political party wanting the application of religious law, on the one hand, and a girl wearing a headscarf on the other. Moreover, it incorporates in its discussion the issue of women's rights without extrapolating on the link between women's rights and the blanket ban and without conducting any practical or normative assessment of how, why and when women's rights are negatively impacted by a hijab. What is absolutely and completely missing is the plethora of writing and debate, feminist and more, surrounding the empowerment of women choosing to wear the hijab. As Tulkens notes;

'it is not for the court's role to make an appraisal of this type... paternalism of this sort runs counter to the case law of the court, which has developed a real right to personal autonomy on the basis of article $8 .{ }^{22}$

In fact, the Court's extrapolation becomes quite ironic insofar as it appears to be concerned by the choice of women to wear or not to wear a hijab but, at the same time, approves a blanket ban preventing any choice from actually being taken by women who want to wear it. As such, the Court's argumentation in relation to the gender element of the headscarf 'could not go beyond superficiality. ${ }^{23}$ Moreover, the Court does not go a step further to consider the gender element of the headscarf ban, namely, that such a measure renders education (or the workplace in the case of Dahlab) an exclusionary setting since "while practicing Muslim males ${ }^{24}$ are not confronted with any obstacles, some Muslim women might be excluded from university because of their religious

\footnotetext{
${ }^{21}$ Leyla Şahin v Turkey, App. No 44774/98 (ECHR 10 November 2005) para.115

${ }^{22}$ Leyla Şahin v. Turkey, App. No. 44774/98 (ECHR 10 November 2005) Dissenting Judgement of Judge Tulkens, para.12

${ }^{23}$ Kerem Altiparmak \& Onur Karahanogullari, 'Case Note: After Sahin: The Debate on Headscarves is Not Over, Leyla Sahin v. Turkey, Grand Chamber Judgment of 10 November 2005, Application No. 44774/98’ (2006) 2 European Constitutional Law Review 2, 288

${ }^{24}$ Note: The circular at Istanbul University did not allow beards on males
} 
choice. ${ }^{, 25}$ In fact, a few years down the line, as will be reflected in the cases below, exclusionary practices of the ECtHR increased, as can be seen in the Court's position on the wearing of the full face veil which essentially 'nullifies a woman's freedom in the public space.' ${ }^{26}$ To complicate matters even more, in S.A.S v France, which came several years later and is discussed further down, the ECtHR held that a country 'cannot invoke gender equality in order to ban a practice that is defended by women ${ }^{27}$ Notwithstanding the negative impact of S.A.S on women with full veils, the Court had not, up until S.A.S, approached the issue of choice, autonomy and gender equality in this manner in relation to the Islamic veil. In reaching this conclusion in S.A.S, it cited Şahin, arguing that a State Party can, instead, prohibit anyone from forcing women to conceal their face and that this aim falls within the protection of the rights and freedoms of others. ${ }^{28}$ However, the authority it relies on involved the alleged but undetermined extremists on campus whose task of forcing women to wear hijabs would allegedly be facilitated if the applicant wore her hijab to university. ${ }^{29}$ The Court in S.A.S seems to thwart the context of Şahin to fit one of its purposes in S.A.S, namely the appearance of the Court as non-patriarchal and a protector of individual autonomy.

As a result of the above, the judgment in Şahin was tainted by an over-reliance on the Turkish Constitutional Court's decision, with an ECtHR appearing not bold enough substantially to investigate allegations of the threat to secularism, a rise in extremism and a violation of democratic values, and an ECtHR not thorough enough adequately to investigate the words it (at times negligently) throws about in its judgments, such as pluralism.

In a nutshell, the Court in both of the above cases essentially found that, notwithstanding the age or capacity of pupils or anyone for that matter, there is no space for the hijab in a democratic society. To make matters worse, it reaches this conclusion without any normative assessment and

\footnotetext{
${ }^{25}$ Kerem Altiparmak \& Onur Karahanogullari, 'Case Note: After Sahin: The Debate on Headscarves is Not Over, Leyla Sahin v. Turkey, Grand Chamber Judgment of 10 November 2005, Application No. 44774/98' (2006) 2 European Constitutional Law Review 2, 288

${ }^{26}$ Gerhard van der Schyff \& Afriaan Overbeeke, 'Exercising Religious Freedoms in the Public Space: A Comparative and European Convention Analysis of General Burqa Bans' (2011) 7 European Constitutional Law Review 3, 441

${ }^{27}$ S.A.S. v. France, App. No 43835/11 (ECHR 1 July 2014) para.119

${ }^{28}$ Ibid. para. 121

${ }^{29}$ Leyla Şahin v. Turkey, App. No 44774/98 (ECHR 10 November 2005)
} 
quickly forgets its earlier judgments which spoke of pluralism. A reminder to the Court, which in 1991 found that:

'Pluralism, tolerance and broadmindedness are hallmarks of a democratic society. Although individual interests must on occasion be subordinated to those of a group, democracy does not simply mean that the views of the majority must always prevail: a balance must be achieved which ensures the fair and proper treatment of minorities and avoids any abuse of a dominant position.' 30

This conceptualisation of pluralism as a central tenet of a democracy and an avenue through which minorities can be empowered, is not embraced by the Court in dealing with Dahlab's hijab, rendering the doctrine almost fictitious when it comes to the exercise of the (Islamic) religion by women wearing a headscarf. As such, on the one (theoretical) hand, the Court talks of pluralism and on the other it dictates what kind of religious 'manifestations' (I use this word with care and will revert to why it is problematic later on) are acceptable in a democratic society, being quick to match the wearing of an Islamic headscarf with a series of unsubstantiated woes. To this end, the Court perceives the hijab as "not only a religious symbol but also a symbol contrary to the western fundamental values. ${ }^{31}$ If this is not an abuse of a dominant position, then I am not sure what is.

\subsection{S.A.S v France, Belkacemi and Oussar v. Belgium, Dakir v Belgium and the Birth of a Brave} New Doctrine.

The applicant in S.A.S argued that the blanket ban on the full face veil in all public spaces in France was a violation of her Article 9 right. Although the judgment commenced with the Court disregarding the public safety argument put forth by France, it subsequently went on to find the restriction legitimate under Article 9 in order to protect the rights of others who, apparently, wish

\footnotetext{
${ }^{30}$ Young, James and Webster v. The United Kingdom (App. Nos. 7601/76; 7806/77) (ECHR 13 August 1988) para. 63

31 Aernout Nieuwenhuis, 'Case Note: State and Religion, Schools and Scarves, An Analysis of the Margin of Appreciation as Used in the Case of Leyla Sahin v. Turkey, Decision of 29 June 2004, Application Number 44774/98' (2005) 1 European Constitutional Law Review 3, 509
} 
to 'live in a space of socialisation which makes living together easier.' ${ }^{32}$ Importantly, the Court in S.A.S and in the later Belgian cases recognised that:

'a State which enters into a legislative process of this kind takes the risk of contributing to the consolidation of the stereotypes which affect certain categories of the population and of encouraging the expression of intolerance, when it has a duty, on the contrary, to promote tolerance.' 33

The major problem of this decision is the concept of 'living together' as a legitimate justification for the ban. As noted in the partly dissenting opinions of Judges Nussberger and Jäderblom, the 'very general concept of living together does not fall directly under any of the rights and freedoms guaranteed within the Convention, ${ }^{34}$ and is, therefore, 'far-fetched and vague.' ${ }^{35}$ In brief, there is neither a right to look at each other's faces under the Convention nor any paradigm on if and how we should socialise in public spaces. As well as illegitimate for Convention purposes, this newly established concept is 'quite puzzling'36 as we do not actually know what it entails, what it amounts to and how it fits into protecting the rights and freedoms of others which was the framework through which the Court justified the concept and the subsequent legitimacy of the restriction. Moreover, the nexus between living together and covering one's face was not adequately extrapolated on. In short, since no such right or paradigm exists, there is no legal justification of the ban for purposes of protecting the rights and freedoms of others. ${ }^{37}$ To complicate matters even further, the Court highlighted that significant doctrines and principles, such as gender equality, human dignity and the minimum requirements of social life could not constitute a legitimate aim but 'living together' could. To this end, it found that:

'The Court takes into account the respondent State's point that the face plays an important role in social interaction. It can understand the view that individuals who are present in

\footnotetext{
${ }^{32}$ S.A.S. v. France, App. No 43835/11 (ECHR 1 July 2014) para. 122

${ }^{33}$ Ibid. para. 149

${ }^{34}$ Ibid. Joint partly dissenting opinion of Judges Nussberger and Jaderblog, para.4

${ }^{35}$ Ibid. para.5

${ }^{36}$ Sune Laegaard, 'Burqa Ban, Freedom of Religion and Living Together' (2015) 16 Human Rights Review 3,206

37 Ibid. 211
} 
places open to all may not wish to see practices or attitudes developing there which would fundamentally call into question the possibility of open interpersonal relationships, which, by virtue of an established consensus, forms an indispensable element of community life within the society in question. 38

This is rather complicated both normatively and legally. On the one hand, the Court held that the fact that wearing a burqa is 'a minority practice is without effect on its legal characterisation.' While acknowledging this, the Court subsequently develops the doctrine of 'living together,' which very much emanates from the wish of an 'established consensus' 39 (of the majority) as to if and how 'community life' is to be developed. This conceptualisation has been defined as the 'community claim' 40 and emanates from the fact that:

'the majority of French citizens disapprove of or simply dislike face covering. As such the statement is clearly true. But if this is the justification for the ban, it collapses into a simple appeal to the majority opinion.' 41

Protecting the safety, health or morals of a society sits comfortably (if conceptualised and contextualised properly) with human rights norms. Protecting most people's preference on how they behave with strangers in parks and streets is quite another issue. So, once again, notwithstanding statements made by the Court about protecting even minority practices, the wish of the majority has prevailed. The general pursuit of the Court of a pluralistic society is, therefore, diluted, given that the ban itself 'constitutes a strong form of state sponsored intolerance of minority practices. ${ }^{42}$ As such, it appears to be the case that the ECtHR did not pay attention to the fact that, because of its role as European supervisor, due care should have been taken so that the Court itself did not contribute to the creation of stereotypes and promotion of intolerance.

\footnotetext{
${ }^{38}$ S.A.S. v. France, App. No 43835/11 (1 July 2014) para. 122

39 Ibid.

${ }^{40}$ Sune Laegaard, 'Burqa Ban, Freedom of Religion and Living Together' (2015) 16 Human Rights Review 3, 209

${ }^{41}$ Ibid.

${ }^{42}$ Ibid. 210
} 
Later cases of Belkacemi and Oussar v Belgium and Dakri v Belgium, which involved applicants contesting the Belgian blanket ban on full face veils, were decided on the same grounds as S.A.S, namely 'living together.' Interestingly, in S.A.S, the Court relied on the government's interpretation of the notion of le "vivre ensemble". In the two Belgian cases, this notion suddenly become a Belgian one too without any sufficient extrapolation as to how and why. In fact, in his separate concurring opinion in Dakir v Belgium, Judge Spano did recognise that the findings in the French case were significant to that case and its context but were not readily transferrable to other cases and States. ${ }^{43}$

Once again, the direct impact is firstly on the women with full face veils who have been confined to their homes. It cannot be overstated that S.A.S and the subsequent Belgian cases involve the absolute prohibition of this group of women from being anywhere but their homes. Beyond the effect on a micro level, namely, on women themselves, it is damaging on a meso level (the group of women wearing full face veils) and a macro level (community ties). The Court is essentially preaching pluralism and minority rights but imposing, through its reasoning, the 'onus...on religious minorities to fix themselves, rather than changing discriminatory practices.' ${ }^{44}$

In brief, restrictions on Islamic dress are deemed legitimate by the ECtHR to, inter alia, meet the requirements of secularism, protect allegedly impressionable children from proselytism, safeguard principles, such as gender equality, and ensure that people in a society can 'live together.' If a comparator did not exist, namely, the treatment of cases involving Christian symbols, it could be argued, as it is in this paper, that the Court's case-law is potentially unfounded, unsatisfactory and plagued with Islamoprejudicial stereotypes. In my view, given that a comparator does exist, I cannot see how any other argument can be put forth regarding the Court's stance and, more particularly, the differentiation in its stance when faced with Islamic manifestation in the form of a hijab, niqab or burqa, on the one hand, and a Christian cross on the

\footnotetext{
${ }^{43}$ Dakir v Belgium, App. No 4619/12 (ECHR 11 July 2017) Concurring opinion of Judge Spano joined by Judge Karakas, para.6

44 Gerhard van der Schyff \& Afriaan Overbeeke, 'Exercising Religious Freedoms in the Public Space: A Comparative and European Convention Analysis of General Burqa Bans' 7 European Constitutional Law Review 3 , 441
} 
other. Turning to the manifestation of the Christian religion, the cases of both Eweida and Others $v$ The United Kingdom and Lautsi and Others $v$ France will be considered.

\subsection{Eweida and Others $v$ The United Kingdom}

Eweida worked for British Airways and wore a crucifix. She was dismissed by her employer for wearing it, since it was in contravention of the company's uniform policy. In finding a violation of Article 9, the ECtHR found that:

'a fair balance was not struck... On one side of the scales was Eweida's desire to manifest her religious belief... On the other side of the scales was the employer's wish to project a certain corporate image.'

While agreeing that the company's desire to portray a particular corporate image was a legitimate aim, the Court held that this aim had been accorded too much weight by the national court. ${ }^{45}$ The Court described the applicant's cross as 'discreet' 46 and unable to have 'detracted from her professional appearance. ${ }^{47}$ Furthermore, the Court underlined that there was no evidence that the wearing of religious items, such as turbans and hijabs, by employees had a negative impact on the company's corporate image. ${ }^{48}$ This finding is important in a comparative perspective as it constitutes a fact-finding and contextual analysis of the case under consideration, rather than an over-reliance on abstract and generalised statements and preconceptions made by the Court in the judgments discussed previously.

In relation to Chaplin, a nurse for the National Health Service who wore the crucifix and was dismissed due to her decision not to remove it, the ECtHR allowed the restriction of Article 9 on the grounds of health and safety. ${ }^{49}$ It was logical and reasonable that the Court found hospital

\footnotetext{
${ }^{45}$ Eweida and Others v The United Kingdom, App. Nos. 8420/10, 59842/10, 51671/10 and 36516/10 (ECHR 27 May 2013) para.94

${ }^{46}$ Ibid.

${ }^{47}$ Ibid.

${ }^{48}$ Ibid.

${ }^{49}$ Ibid.
} 
managers to be 'better placed to make decisions about clinical safety than a court, particularly an international court which heard no direct evidence.' 50

The Court took a more pragmatic approach to Eweida and Chaplin's situations, looking at the actual impact of their religious 'manifestations' and, absent the stereotypes and generalisations that are carried over to Strasbourg with judgments of national courts, stepped away from abstract and generic findings and conclusions. Although the above two applications are clear and legally reasonable, taken alone and in conjunction with each other, I would wish to have seen the pragmatic fact-finding conducted in both, namely, what is the problem and what is the real impact of the religious manifestation on others in cases on Islamic dress discussed above. I would also have wished to see the line of reasoning set out in Eweida and the balance test adopted, therein, transferred to the Court's analysis in Ebrahimian v France. I have chosen to discuss this case here rather than with the other cases involving Islam, given that it is directly related to the workplace and, at least on a phenomenological level, has no 'baggage' in the form of impressionable children or a context of strife between secularism and religion nor does it involve the more contested and difficult to assess full face veil in the form of the niqab or burqa. In Ebrahimian, the applicant did not have her employment contract renewed as social assistant of a State psychiatric unit following complaints by certain patients being treated at the Centre that that the applicant refused to stop wearing her hijab. Here, the Court made a quick assessment of the importance of upholding secularism in State run institutions and replaced impressionable children (Dahlab), women who did not want to wear the hijab but would be forced to do so by extremists (Sahin) and people in parks, streets and malls (S.A.S) with 'people in a vulnerable situation.' The nexus between the vulnerability of the people and the requirement not to wear a headscarf was never extrapolated on, whilst the impact of the applicant's hijab on secularism was not adequately investigated. Rather, the Court found that the prohibition of the applicant's hijab was:

'to ensure respect for all of the religious beliefs and spiritual orientations held by the patients who were using the public service and were recipients of the requirement of neutrality imposed on the applicant, by guaranteeing them strict equality. ${ }^{, 51}$

${ }^{50}$ Ibid. para.99 
It did not, however, conceptualise on how the applicant was disrespecting persons of other religious beliefs or spiritual orientations or how their equality in the framework of the psychiatric unit and the services they received from there were negatively affected. In fact, the Director of Human Resources received complaints from some beneficiaries of the psychiatric unit regarding the applicant's hijab rather than the quality of her work or her attitude towards people of other faiths. Further, the Court acknowledged that the applicant had not been accused of pressure, provocation or proselytism but that the perception of her veil as an 'ostentatious manifestation of her religion'52 was incompatible with the neutral environment. It is, to say the least, disappointing that the Court accepts the perception of the veil as 'ostentatious' to constitute an accepted and acceptable perception which underlies subsequent judicial reasoning. As such, the fact-finding approach of the actual impact of the religious manifestation on others, as conducted in Eweida and Others, was absent, the customer satisfaction threshold granted unduly high importance and the generalisations veiled by the undefined and little or misunderstood by the Court doctrine of secularism. As a result, the Court restricted the applicant's right to exercise her religion, a right which the same court has deemed vital for religious individuals and for a pluralist society, essentially in the name of customer preference.

\subsection{Lautsi and Others $v$ Italy}

This case was brought by Lautsi and her children, who had reached the age of majority by the time the case came to the ECtHR. They claimed that their Article 9 right, in their case to be free from religious belief, was violated as a result of the fixation of the crucifix on their State classroom walls. Emanating from the reasoning in Dahlab, the Chamber found that the crucifixes on the walls of public schools were 'impossible not to notice' ${ }^{53}$ and were 'necessarily perceived as an integral part of the school environment and could therefore be considered powerful external symbols. ${ }^{54}$ The Chamber decision in Lautsi and Others $v$ Italy was met with an 'uproar' in

${ }^{51}$ Ebrahimian v France, App. No 64846/11_(ECHR 26 February 2016) para. 53

52 Ibid. para.62

${ }^{53}$ Lautsi and Others v Italy, App. No 30814/06 (ECHR 18 March 2011) para.73

${ }^{54}$ Ibid. 
Italy ${ }^{55}$ and caused 'shockwaves throughout Europe. ${ }^{56}$ There has been no equivalent in reaction when women wearing the hijab have been prevented from going to work, going to university or when women in the niqab or burqa have been restricted to their homes. This reflects that the structure of a State and the impact of the majority are seen on a judicial as well as on a political and social level. Italy's referral of the case to the Grand Chamber attracted the intervention of ten States, thirty-three parliamentarians and six NGOs.

The Grand Chamber reversed that decision, finding that, unlike Dahlab, which the Chamber had relied on, the crucifix was a 'passive external symbol. ${ }^{57}$ The Grand Chamber further held that the "presence of crucifixes is not associated with compulsory teaching about Christianity. ${ }^{58}$ The Court referred to the fact that the applicants 'did not assert that the presence of the crucifix in classrooms had encouraged the development of teaching practices with a proselytising tendency. ${ }^{59}$ Of course, the wearing of the hijab by Dahlab did not mean that she was preaching Islam to her pupils but this was not a consideration in her case. In fact, as mentioned above, no complaint had been made by parents or the inspector about her teaching, but she still had to remove the hijab if she wanted to keep her job, and the Court completely disregarded this central element of the actual impact of her hijab on her pupils. In relation to the actual impact, as pertinently noted by Judge Rozakis joined by Judge Vadic in their concurring opinion in the Grand Chamber decision on Lautsi:

'Most of us now live in multicultural, multi-ethnic societies within our national states, a feature which has become a common characteristics of those societies and children living in that environment are exposed, in their everyday life, to ideas and opinions which go beyond those emanating from school and their parents. Human relations outside the parental roof and modern means of communication undoubtedly contribute to that effect. As a consequence children become accustomed to receiving a variety of frequently conflicting ideas and

\footnotetext{
${ }^{55}$ Gabriel Andreescu \& Liviu Andreescu, 'The European Court of Human Rights' Lautsi Decision: Context, Contents, Consequences' (2010) 9 Journal for the Study of Religions and Ideologies 26, 50

${ }^{56}$ Nicolas Bratza, 'The Precious Asset: Freedom of Religion Under the European Convention on Human Rights' (2012) 14 Ecclesiastical Law Journal 2, 269

${ }^{57}$ Ibid. para. 72

${ }^{58}$ Ibid. para. 74

${ }^{59}$ Ibid. para.74
} 
opinions and the role of both school and parents in these matters has become relatively less influential. ${ }^{60}$

This appraisal is apt, real and reflective of today's European societies. It also facilitates the move away from the paternalism associated with what children can handle and what they cannot. Alone, it is great and one would have wished to see such an analysis conducted by the majority opinions in judgments involving Islamic dress.

Lautsi and Others $v$ Italy was a controversial case by anyone's standards. For this author, the controversial aspect of this case does not emanate from the Chamber's decision that the presence of a crucifix in the classroom affects the exercise of Article 9. Alas, it was simply following previous lines of reasoning, such as that set out and accepted in Dahlab. Instead, the controversial aspect emanates from the way in which Europe and, subsequently, the Grand Chamber responded to the Chamber's decision, a process and result which embody the thesis of this paper, namely, that some are just more equal than others in regard to, inter alia, how, when and why they exercise their freedom of religion. It must be underlined that this author is in agreement with the Grand Chamber decision in Lautsi, standing alone, and does not consider that what has been defined as 'aggressive secularism' ${ }^{\prime}$ is in line with human rights law. The problem lies at the vast and unsubstantiated divergence between Dahlab and Lautsi. I could almost guarantee that, had Dahlab been decided in a different manner, namely, embracing the permissibility of the hijab in a State school and reconciling the perceived disparity between secularism and religious manifestation, the Chamber judgment would be different. What the Court needs to stop doing is fuelling the double standards it has created in relation to the 'manifestation' of freedom of religion in the form of symbols and clothes.

\subsection{The Margin of Appreciation: The Majority's Weapon?}

In light of the above, in relation to Islamic dress, the Court has always catered for the position of the State. It has done so through a mixture of generalisations, discussed above, but also through

\footnotetext{
${ }^{60}$ Lautsi and Others v Italy, App. No 30814/06 (ECHR 18 March 2011) Concurring opinion of Judge Rozakis joined by Judge Vadic

${ }^{61}$ Dominic McGoldrick, 'Religion in the European Public Square and the European Public Life - Crucifixes in the Classroom' (2011) 11 Human Rights Law Review 3, 452
} 
the doctrine of the margin of appreciation. It is beyond the scope of the present paper to dive into an analysis of the margin, but, it is, however, significant to consider the role this margin had in the aforementioned decisions and how the doctrine contributed to the variation that exists between how the different 'symbols' have been treated by the Court. A margin of appreciation is given to States when opinions differ within a democratic society and there is an absence of European consensus on the theme. ${ }^{62}$ However, there has never been any substantial discussion as to what constitutes consensus and what threshold needs to be crossed for there to be a finding of no consensus. In such cases, the Court recognises that the domestic authorities should have more power to decide on the issues at stake. The margin of appreciation which has been described to be 'as slippery and elusive as an eel' ${ }^{\prime 63}$ goes 'hand in hand with a European supervision,' ${ }^{64}$ a supervision that has proved rather toothless in cases involving Islamic 'manifestation' in the form of veils. As noted by Judge Tulkens in her dissenting opinion, 'European supervision seems quite simply to be absent from the judgment. ${ }^{65}$ Giving a margin of appreciation to States does not mean that the Court simply sits back and accepts the argumentation put forth by the government. Unfortunately, in, inter alia, Sahin, the Court did exactly that, embracing and transposing into its own decisions the approach and conceptualisation of themes such as extremism, secularism and gender equality by Turkey, without any substantial analysis and investigation into these themes or into the particular case and its facts.

This has resulted in the Court relying on the doctrine too easily, the effects of which have been damning to individuals who want to exercise rights that are not embraced by State structures but which fall within the realm of the ECHR. This doctrine allows the embedded structures of the States in the form of its judiciary and policy-makers, to dictate what is acceptable practice and what is not in areas where there is supposedly no consensus and, as such, constitutes a weapon for the majority given that it is their members which predominantly make up these structures in European societies. As such, it leaves:

\footnotetext{
${ }^{62}$ S.A.S. v. France, App. No 43835/11 (ECHR 1 July 2014) para.156

${ }^{63}$ Anthony Lester, 'Universality vs. Subsidiarity: A Reply' (1998) 1 European Human Rights Law Review, 75

${ }^{64}$ Leyla Şahin v, Turkey, App. No 44774/98 (ECHR 10 November 2005) para.110

${ }^{65}$ Ibid. Dissenting judgement of Judge Tulkens, para.3
} 
'minority rights and interests vulnerable to the power of the majority (as represented by the State), making it dangerous for the boundaries of protection to be set by reference to majority opinion. ${ }^{66}$

This is an anathema to human rights law and is in direct contravention of the aims of the Convention and the jurisprudence of the Court which notes, even if it does not itself abide by this in practice on many occasions, that majority opinions should not override their minority counterparts. A reminder of this point is the acknowledgement of the ECtHR in Şahin that:

'...democracy does not simply mean that the views of a majority must always prevail: a balance must be achieved which ensures the fair and proper treatment of people from minorities and avoids any abuse of a dominant position.' 67

The Court acknowledges and underlines the above but, simultaneously, facilitates the domination of the majority over the minority through the use of the margin of appreciation doctrine which it has, over time and cases, relied on too easily.

Briefly, the use of this margin, especially a broad margin, habitually used in cases involving Islamic dress, negatively affects the quality of the test that needs to be followed. In the cases examined above involving Islamic dress, the necessity requirements emanate from a simple transposition of the State's position; the proportionality analysis is almost non-existent and the legitimate aim is easily tampered with, as in S.A.S. It appears that the ECtHR, either due to lack of boldness or as a result of something more sinister, simply deals with all cases of Islamic dress through the enforcement of the margin of appreciation ${ }^{68}$ and, thus accommodates State views and practices.

\subsection{The ECtHR's theological conceptualisation of religious 'symbols'}

\footnotetext{
${ }^{66}$ Lucy Vickers, 'Achbita and Bougnaoui: One Step Forward and Two Steps Back for Religious Diversity in the Workplace' (2017) 8 European Labour Law Journal 3, 245

${ }^{67}$ Leyla Şahin v. Turkey, App. No 44774/98 (ECHR 10 November 2005) para.108

68 Gabriel Andreescu \& Liviu Andreescu, 'The European Court of Human Rights' Lautsi Decision: Context, Contents, Consequences’ (2010) 9 Journal for the Study of Religions and Ideologies 26, 48
} 
Article 9 provides for the freedom of religion, including its manifestation. The construction of the article is the first point of complication. In drafting a legal document, namely the ECHR, a theological conceptualisation of religion was, probably inadvertently, effectuated. More particularly, religion as a belief system and world-theory constitutes our forum internum, which no one can touch and no one needs to since it does not affect anyone else (it is all in our heart and souls). However, when we want to manifest (synonym to that being show) our religion in the form of dress, symbols or others, this constitutes our forum externum, what we present to the outside world regarding our religious belief.

In his discussion on Achbita, which was heard by the CJEU, Weiler made the following statement which is relevant to the present discussion on the ECHR and the ECtHR:

'It is not my intention at all to suggest that Christian believers, unlike their Jewish or Muslim brothers or sisters, leave their faith outside the precincts of the workplace. But the way they live their faith in the workplace is through their ethical conduct, their love of their fellow worker and the like, which constitutes testimony of the living Christ. For the most part of Christianity has abjured the myriad of ritualistic practices which characterise Islamic and Jewish nomos. It is mostly a religion of the heart. Your Christianity in such circumstances is not manifested by what you wear what you eat and the like but how you behave.' 69

Therefore, any manifestation of the Christian faith constitutes a clear-cut case of the forum externum. However, by wearing the cross the Christian is simply wearing an identity, he or she is not, through the wearing of the cross, abiding by any religious duty or conducting a spiritual exercise. This is unlike the hijab, the wearing of which is mandated in the Koran and, in wearing it, Muslim women are embracing values such as modesty, which is so central to the Muslim faith. Therefore, this does not fit into the clear cut separation of the forum internum and forum externum which is manifested in Article 9. You cannot tell a Muslim woman that she is wearing a hijab because she simply wants to show her religious identity, as is the case with the Christian person wearing a crucifix. Instead, she is living her religion and its values through the hijab

\footnotetext{
${ }^{69}$ Joseph H.H. Weiler, 'Case Comment: Je Suis Achbita' (2017) 28 European Journal of International Law 4, 994
} 
which goes beyond symbolism, manifestation and the forum externum to religious spirituality and practice. The distinction and conceptualisation of Article 9 in the form of the inward faith and how it is expressed outwardly, therefore, very much fits the Christian model described above, although it is not so accommodating for Islam. The Court, in its interpretation of Article 9, has not been open to developing this article in such a way as to accommodate for faiths which do not have such a clear cut separation, as the margin of appreciation has come in so quickly for cases involving Islamic dress, decreasing the quality of any substantial assessment. The result of the substance and conceptualisation of Article 9 by the ECHtR is that women, in the cases discussed above, are not just prevented from showing their faith, they are prevented from obeying and living it. Further, it has been argued that the 'the court has failed meaningfully to acknowledge the deep commitments that manifestations of religion/belief may represent from the perspective of believers themselves. ${ }^{, 70}$ I would agree with this statement to an extent, namely. in relation to how the Court has approached Islamic dress. It has never really tried to understand what a hijab, burqa or niqab represent and has never really assessed the link between the veils and the wearers of the veils in terms of religious and spiritual duty and observance. In relation to the Christian crucifix, it was empathetic and understanding since that symbol was simply much closer to home, if not the home itself.

\section{Conclusion: ECtHR Jurisprudence}

In sum, the protection offered by the ECtHR to Muslim women wanting to exercise their religion by wearing a veil (a hijab, niqab or burqa) is weak. Despite several applications made by Muslim women to Strasbourg, none has been successful. The Court is not adequately balancing individual rights, on the one hand, and other concerns on the other, which is a central element of their role as protectors of the ECHR. Further, the Court has been over-zealous in granting the margin of appreciation to States Parties, in all relevant cases, in a way that satisfies the majority position. The only relevant time where the Chamber decided against the embedded State structure was in Lautsi v Italy. That 'mishap' was quickly taken care of by the Grand Chamber. The Court has also been creative in developing the substance and meaning of the 'rights and

\footnotetext{
${ }^{70}$ Peter Cumper \& Tom Lewis, 'Empathy and Human Rights: The Case of Religious Dress' (2018) 18 Human Rights Law Review 1, 63
} 
freedoms of others' as a legitimate aim by developing the doctrine of 'living together' in order to allow blanket bans on burqas and niqabs. In addition, this Christian inspired binary nature (forum internum and forum externum) of Article 9 as well as the Court's jurisprudence, individually and in combination with each other, do not accommodate for the reality of Muslim women. And, once again, the effect of all the above is that Muslim women are facing increasing obstacles in the workplace, their education and even their neighbourhoods and parks. So much for a pluralist democracy and for freedom of religion constituting a central tenet of the life of believers.

\section{Court of Justice of the European Union: The Damned Veil of Neutrality}

In March 2017, the CJEU decided its first cases involving religious discrimination in employment within the framework of Council Directive 2000/78/EC, establishing a general framework for equal treatment in employment and occupation. The cases involved Ms. Achbita, an employee for G4S Security in Belgium, who was asked to remove her hijab to abide by the general neutrality policy of the company and Ms. Bougnaoui, an employee of Micropole, who was asked to remove her headscarf after a client had complained about it. As will be reflected in the below analysis, these cases reflect 'a missed opportunity to develop the EU law on religious discrimination in a way that serves both the equality aims of the underpinning Directive and the cause of European integration more generally. ${ }^{71}$ Moreover, the two cases constituted a framework through which the CJEU could have altered the disappointing approach adopted by the ECtHR to the hijab worn in, inter alia, the workplace and put Europe on the right path to protecting the exercising of religious freedoms for all people, including those belonging to minorities.

\subsection{Samira Achbita and Centrum voor gelijkheid van kansen en voor racismebestrijding v} G4S Secure Solutions NV

Achbita is "not a run of the mill case"72 which involved a series of legal and social issues and which revealed the hypocrisy of the alleged integration and social cohesion efforts of the European Union. Regarding the basic facts of the case, there was an unwritten rule that G4S

\footnotetext{
${ }^{71}$ Lucy Vickers, 'Achbita and Bougnaoui: One Step Forward and Two Steps Back for Religious Diversity in the Workplace’ (2017) 8 European Law Journal 3, 233

72 Joseph H.H. Weiler, 'Case Comment: Je Suis Achbita' (2017) 28 European Journal of International Law 4, 989
} 
workers could not wear any visible signs of their political, philosophical or religious beliefs at work. Achbita had informed the management that she would commence wearing her headscarf at some point in the future. She was told that this would not be tolerated. In May 2006 this previously unwritten rule was incorporated into the workplace regulations which came into force in June 2006. The regulations held that:

'Employees are prohibited, in the workplace, from wearing any visible signs of their political, philosophical or religious beliefs and/or from engaging in any observance of such beliefs. ${ }^{73}$

In the same month, Achbita was dismissed on the grounds that she was not complying with the regulations since she would not remove her hijab. The referring court asked the CJEU

'...whether Article 2.2(a) of Directive 2000/78 (direct discrimination) must be interpreted as meaning that the prohibition on wearing an Islamic headscarf, which arises from an internal rule of a private undertaking imposing a blanket ban on the visible wearing of any political, philosophical or religious sign in the workplace constitutes direct discrimination that is prohibited by that directive. ${ }^{, 74}$

Before turning to the Court's judgment, it is significant to look at a particular element of Advocate General (AG) Kokott's opinion in relation to the role of religion in people's lives. The Advocate General held that:

'While an employee cannot leave his sex, skin colour, ethnicity, sexual orientation, age or disability 'at the door' upon entering his employer's premises, he may be expected to moderate the exercise of his religion in the workplace, be this in relation to religious practices, religious motivated behaviour or (as in the present case) his clothing.' 75

\footnotetext{
${ }^{73}$ Samira Achbita and Centrum voor gelijkheid van kansen en voor racismebestrijding v G4S Secure Solutions NV, ECLI:EU:C:2017:203, para.15

${ }^{74}$ Ibid. para. 22

${ }^{75}$ Advocate General Opinion, Samira Achbita and Centrum voor gelijkheid van kansen en voor racismebestrijding v G4S Secure Solutions NV, ECLI:EU:C:2016:382, para.116
} 
This is a dangerous observation which runs contrary to the very essence of the freedom of religion and the very role religion plays in religious people's lives. It is a direct strike and subdual of religion and an unfounded comparator of the importance and weight accorded to religion as a characteristic by the directive. Nowhere in the directive or its recitals has hierarchy of importance been attached according to the particular characteristic. AG Kokott essentially held that some characteristics are just more equal than others. In addition, by demeaning the very essence and importance of freedom of religion, the AG did, in fact, diminish the scope and role of the directive itself. Thankfully, the AG in Bouganoui discussed next was very different. More particularly, in that opinion, AG Sharpston recognised the intrinsic need for religious individuals to live and abide by the precepts laid down in their religion. More particularly, she held that:

'Someone who is an observant member of a faith, religious identity is an integral part of that person's very being. The requirements of one's faith - its discipline and the rules that it lays down for conducting one's life - are not elements that are to be applied when outside work.' 76

In addition, she underlined that 'it would be entirely wrong to suppose that, whereas one's sex and skin colour accompany one everywhere, somehow one's religion does not. ${ }^{, 77}$

The opinion, thereby, rectified, at least on a normative level, the sour taste left by Kokott's conceptualisation of religion.

Turning now to the judgment, the CJEU held that an internal rule of this sort which applies to characteristics beyond religion does not introduce a difference in treatment for purposes of Article 2.2(a) of the Directive. ${ }^{78}$ It reached this decision by looking at the apparently neutral character of the policy and of the way it was applied. Firstly, the CJEU held that the policy

\footnotetext{
${ }_{76}$ Advocate General Opinion, Asma Bougnaoui and Association de défense des droits de l'homme (ADDH) v Micropole SA, ECLI:EU:C:2016:553, para.118

${ }^{77}$ Ibid.

78 Asma Bougnaoui and Association de défense des droits de l'homme (ADDH) v Micropole SA, ECLI:EU:C:2017:204, para. 32
} 
applied to a variety of belief systems, not just religious ones, and held that, as such, it should be regarded as 'treating all workers of the undertaking in the same way, by requiring them in a general and undifferentiated way, inter alia, to dress neutrally...' ${ }^{79}$ Furthermore, the CJEU reached the conclusion, without extrapolating on how and why, that it was not evident from the material presented that the internal rule 'was applied differently to Ms. Achbita as compared to any other worker.' ${ }^{80}$ In discussing whether there was a possibility of indirect discrimination, the CJEU left it up to the national court to decipher whether the apparently neutral obligation of the policy placed persons of a particular religion or belief at a particular disadvantage. ${ }^{81}$

As noted by Davies, this observation 'in an essay...might be enjoyed as dry humour. In a judgment, it is bizarre and irresponsible. ${ }^{82}$ It is nothing but evident that the majority of employees (if not all) that would be affected by this policy would be Muslim women, Orthodox Jews and Sikh men, with the wearing of the Christian crucifix not constituting a central precept of the Christian faith. The desire for most people to demonstrate their attachment to socialism or ethical omnivorism cannot be compared to the inherent duty felt by religious individuals to live in their faith while the spiritual requirement to wear a crucifix is not mandated in the Bible. To complicate further the possibility of finding discrimination concealed under the veil of neutrality, the Court underlined that such a difference of treatment does not constitute indirect discrimination if it sought to meet a legitimate aim in an appropriate and necessary manner. ${ }^{83}$ The CJEU further underlined and placed great importance in the employer's wish to portray a neutral image and that this wish falls within the realm of Article 16 of the Charter of Fundamental Rights of the EU on the freedom to conduct a business. Rather bizarrely, in finding the pursuit of that right to constitute a legitimate aim, it referred to the ECtHR judgment in Eweida and Others $v$ The United Kingdom, in which the Court found in Eweida's application that the national court had placed too much weight on British Airway's wish to maintain a particular corporate image, subsequently finding in favour of Eweida. As well as placing

\footnotetext{
${ }^{79}$ Samira Achbita and Centrum voor gelijkheid van kansen en voor racismebestrijding v G4S Secure Solutions NV, ECLI:EU:C:2017:203, para.30

${ }^{80}$ Ibid. para. 31

${ }^{81}$ Ibid. para.34

${ }^{82}$ Gareth Davies, ‘Achbita v G4S: Religious Equality Squeezed between Profit and Prejudice' (2017) European Law Blog, available at: <https://europeanlawblog.eu/2017/04/06/achbita-v-g4s-religious-equality-squeezed-betweenprofit-and-prejudice/> [Accessed $1^{\text {st }}$ March 2018]

${ }^{83} \mathrm{Ibid}$. para. 35
} 
particular importance to this right and characterising it as a legitimate aim, the Court made another observation, which can be deemed worrying. It held that it was a legitimate aim insofar as it is enforced for 'those workers who are required to come into contact with the employer's customers. ${ }^{84}$ The Court reinforced this idea of employee-client links in its reasoning by holding that it was for the referring court to decide whether:

'taking into account the inherent constraints to which the undertaking is subject and without G4S being required to take on an additional burden, it would have been possible for G4S faced with such a refusal [to remove the hijab] to offer her a post not involving any visual contact with those customers instead of dismissing her.'

When considering the aims of the directive, namely, to establish a framework of equality in employment, the current reality many women in headscarves face in Europe and the general policy of the European Union to promote integration and social cohesion, the choice of the word 'burden' is rather disappointing as well as the alternative offered by the Court to employers, namely hide those who cause you trouble because their religious or other beliefs are not attractive for your clients. As argued by Butler, 'the suggested proportionality exercise hints at ghettoization - those who want to manifest their religion or belief will be hidden from sight.' 85

Therefore, the internal policy pursued the eradication of political, philosophical and religious symbols (not just religious ones) and was, therefore, neutral. If this policy were applied disproportionately to affect religious groups, then it could fall within the framework of indirect discrimination, which could not anyhow be relied on if the policy pursued a legitimate aim, with the conduct of business constituting such an aim if applied to all employees whom clients could see. So, an employer, to avoid the possibility of indirect discrimination, if there was first proof that the policy was being applied in a disproportionate manner, could, anyhow, get away with it by placing the employees who they did not want to be seen in back offices, insofar as this would

\footnotetext{
${ }^{84}$ Samira Achbita and Centrum voor gelijkheid van kansen en voor racismebestrijding v G4S Secure Solutions NV, ECLI:EU:C:2017:203, para.37

${ }^{85}$ Sarah Fraser Butler, 'Case Comment: The CJEU confused over religion' (2017) 76 Cambridge Law Journal 2, 159
} 
not constitute too much of a burden for them. The damning result of Achbita was that the Court 'may well have weakened or effectively neutralised EU anti-discrimination law.' ${ }^{86}$

\subsection{Bougnaoui and Association de défense des droits de l'homme (ADDH) v Micropole SA}

In this case, Bougnaoui was working for Micropole SA. Following a visit to a client she received the following letter from her employer:

'Following that work, the customer told us that the wearing of a veil, which you in fact wear every day, had upset a number of its employees. It also requested that there should be 'no veil next time.' Since you would be in contact internally or externally with the company's customers, you would not be able to wear the veil in all circumstances. In the interests of the business and for its development we are obliged, vis-a-vis our customers, to require that discretion is observed as regards the expression of the personal preferences of our employees.'

Bougnaoui did not conform to this requirement and was subsequently dismissed. The referring court asked the CJEU a narrower question than that in Achbita, namely:

'whether Article 4.1 of the Directive must be interpreted as meaning that the willingness of an employer to take account of the wishes of a customer no longer to have that employer's services provided by a worker wearing an Islamic headscarf constitutes a genuine and determining occupational requirement within the meaning of that provision. ${ }^{87}$

It must be noted that the question did not allude to the technical capacity of Bougnaoui to conduct her duties as a design engineer while wearing her headscarf, but rather "whether the ability to satisfy the cultural expectations and prejudices of customers should be seen as a

\footnotetext{
${ }^{86}$ Stephanie Hennette-Vauchez, 'Case Comment: Equality and the Market: The Unhappy Fate of Religious Discrimination in Europe' (2017) 13 European Constitutional Law Review 4, 745

87 Asma Bougnaoui and Association de défense des droits de l'homme (ADDH) v Micropole SA, ECLI:EU:C:2017:204
} 
genuine occupational requirement as part of the job. ${ }^{88}$ The Court pointed out that 'it is only in very limited circumstances that a characteristic related, in particular, to religion may constitute a genuine and determining occupational requirement. ${ }^{89}$ It underlined that occupational requirements could reject certain characteristics by reason of the very nature of the particular activities but not the subjective desires and tastes of the customer. ${ }^{90}$

Consequently, the answer to the question is that Article 4.1 of Directive 2000/78 must be interpreted as meaning that the willingness of an employer to take account of the wishes of a customer no longer to have the services of that employer provided by a worker wearing an Islamic headscarf cannot be considered a genuine and determining occupational requirement within the meaning of that provision. In light of the above, the CJEU thankfully and probably because of the very nature of the narrow question posed which was not veiled by accepted doctrines such as that of neutrality, found in Bougnaoui's favour. The EU's non-discrimination framework does not cater for prejudicial needs of customers. In relation to Bougnaoui, the outrageous request of the client, the absence of any neutrality claim or policy and the narrow request of the referring court, established a setting in which the CJEU could not really decide on any differently. In short, we should not get too excited that the CJEU decided in Bougnaoui's favour.

In Achbita, the CJEU was deceived consciously or unconsciously by the veil of neutrality and in Bougnaoui decided that employers cannot cater for subjective prejudicial needs. The cases raised issues not only of law but also of society and, more particularly, Europe's social agenda marked by, inter alia, the integration of minorities. Unfortunately, both the opinion of the AG and the judgment of the CJEU in Achbita did not conceptualise the social aspect either of the issues at stake or of the impact of the ruling. Interestingly, Kokott started off her opinion by acknowledging that:

\footnotetext{
${ }^{88}$ Gareth Davies, 'Achbita v G4S: Religious Equality Squeezed between Profit and Prejudice' (2017) European Law

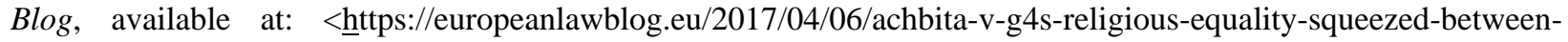
profit-and-prejudice/> [Accessed $1^{\text {st }}$ March 2018]

${ }^{89}$ Samira Achbita and Centrum voor gelijkheid van kansen en voor racismebestrijding v G4S Secure Solutions NV, ECLI:EU:C:2017:203, para.38

${ }^{90}$ Ibid. para. 39
} 
' Ultimately the legal issues surrounding the Islamic headscarf are symbolic of the more fundamental question of how much difference and diversity an open and pluralistic European society must tolerate within its borders, and, conversely how much assimilation is permitted to require from certain minorities.' 91

She seems to have misconceived the nature and characteristics of an open and pluralist society as she speaks of assimilation and toleration. Is she saying that we need to assimilate minorities, decide what habits and practices we can tolerate and remove those which we consider do not match our society? It was not only her choice of words in her opening to the opinion which demonstrate her philosophy of how our society should be organised, it was also the substance of her opinion too. Religion is not as important a characteristic as others protected in the Directive. Members of the minorities who want to manifest their religion should leave their religion outside the workplace and forget about their faith during those hours in order to achieve assimilation and so that we, as the majority, are able to tolerate them. Alas, this does not affect us because we (the majority) do not really need to show our religious identity at work or anywhere because we are either agnostic, atheist or Christian, and, therefore, do not need to wear and show something at work. The day that was published was a sad one both for Achbita herself, the NGO supporting her, the directive and the path of social cohesion and empowerment (not assimilation) that the EU is supposedly on. Whatever the opinion of AG Kokott, the fact remains that women in headscarves are the primary targets (conscious or unconscious) of neutrality clauses and policies, with the CJEU not taking any steps in Achbita to unravel this. Instead it paradoxically chose to place the duty on the national court to discover whether or not neutrality policies were implemented disproportionately rather than seeing the reality that, by default, they would be.

\section{CONCLUSION}

In conclusion, it just seems that the ECtHR 'cannot bring itself to look through the eyes of such a very different other' creating an 'odious bias inherently favouring Christian religions within the espace juridique. ${ }^{92}$ Christian crucifixes, defined as passive symbols, have been allowed to

\footnotetext{
${ }^{91}$ Advocate General Opinion, Samira Achbita and Centrum voor gelijkheid van kansen en voor racismebestrijding v G4S Secure Solutions NV, ECLI:EU:C:2016:382, para.78

${ }^{92}$ Hin-Yan Liu, 'The Meaning of Religious Symbols after the Grand Chamber Judgment in Lautsi v Italy' (2011) 6 Religion and Human Rights 3, 255
} 
remain in the classroom and to be worn by company employees as long as they do not affect health and safety rules. On the other hand, the ECtHR has allowed the dismissal of a primary school teacher wearing a headscarf because of, inter alia, the possible proselytising effects of her headscarf and the negative gender and equality messages that result from women wearing it. The Court has also allowed the dismissal of a social assistant in a State psychiatric unit in the name of secularism and the protection of the 'vulnerable' beneficiaries of the service. The Court has legitimised the banning of a medical student from her classes and exams because she was wearing a hijab and has allowed the group entrapment of all women wearing full-face veils from public spaces in adherence to the French-Belgian notion of 'living together.' The CJEU did not change Strasbourg's wrong direction as it did 'not take the opportunity to establish strong standards for the protection of religious equality. ${ }^{93}$ It did not deconstruct the doctrine of neutrality or assess the reality of the disproportionate impact of such a policy on Muslim women. Even if it had done, it must be underlined that, for the moment, European Union law can only directly tackle religiously discriminatory conduct in the sphere of employment and occupation, given the nature of the aforementioned directive and the absence of a directive that goes beyond the designated context. What is further missing from case-law of both the ECtHR and the CJEU is proper reasoning and justification which is central for the applicants and is part of the 'culture of justification, ${ }^{, 94}$ without which, these (women) are, essentially victimised twice; once by their employers, universities or policy makers and once by the Courts themselves. If you are going to tell a woman to stop practising her religion and living within that spiritual arena, you need properly to explain why rather than generalise and/or shy away from deconstructing the potentially real aims of doctrines such as neutrality and secularism. The bottom line is that the two Courts have not set adequate benchmarks of protection for religious minorities and have not conceptualised themselves as key players to fight the growing Islamoprejudice marking a plethora of European realms. Instead, they have either reiterated negative narratives or hidden behind the acceptable shield of neutrality.

\footnotetext{
${ }^{93}$ Lucy Vickers, 'Achbita and Bougnaoui: One Step Forward and Two Steps Back for Religious Diversity in the Workplace' (2017) 8 European Labour Law Journal 3, 252

${ }^{94}$ Megan Pearson, 'Article 9 at a Crossroads: Interference Before and After Eweida' (2013) 13 Human Rights Law Review 3, 582
} 


\section{BIBLIOGRAPHY}

\section{Cases: European Court of Human Rights}

Dahlab v Switzerland, App. No 42393/98 (ECHR 15 February 2011)

Dakir v Belgium, App. No 4619/12 (ECHR 11 July 2017)

Ebrahimian v France, App. No 64846/11(ECHR 26 February 2016)

Eweida and Others v The United Kingdom, App. Nos. 8420/10, 59842/10, 51671/10 and 36516/10 (ECHR 27 May 2013) 


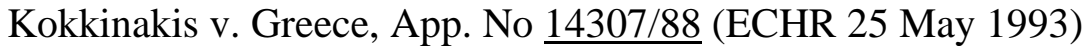

Lautsi and Others v Italy, App. No 30814/06 (ECHR18 March 2011)

Leyla Şahin v Turkey, App. No 44774/98 (ECHR 10 November 2005)

S.A.S. v. France, App. No 43835/11 (ECHR 1 July 2014)

Young, James and Webster v The United Kingdom (App. Nos. 7601/76; 7806/77) (ECHR 13 August 1988)

Cases/AG Opinions: Court of Justice of the European Union

Asma Bougnaoui and Association de défense des droits de l'homme (ADDH) v Micropole SA, ECLI:EU:C:2017:204

Samira Achbita and Centrum voor gelijkheid van kansen en voor racismebestrijding v G4S Secure Solutions NV, ECLI:EU:C:2017:203

Advocate General Opinion, Asma Bougnaoui and Association de défense des droits de l'homme (ADDH) v Micropole SA, ECLI:EU:C:2016:553

Advocate General Opinion, Samira Achbita and Centrum voor gelijkheid van kansen en voor racismebestrijding v G4S Secure Solutions NV, ECLI:EU:C:2016:382

\section{Journal articles:}

Altiparmak K \& Karahanogullari O, 'Case Note: After Sahin: The Debate on Headscarves is Not Over, Leyla Sahin v. Turkey, Grand Chamber Judgment of 10 November 2005, Application No. 44774/98' (2006) 2 European Constitutional Law Review 2

Andreescu G \& Andreescu L, 'The European Court of Human Rights' Lautsi Decision: Context, Contents, Consequences' (2010) 26 Journal for the Study of Religions and Ideologies 26

Bratza N, 'The Precious Asset: Freedom of Religion under the European Convention on Human Rights’ (2012) 14 Ecclesiastical Law Journal 2

Butler S, 'Case Comment: The CJEU Confused over Religion' (2017) 76 Cambridge Law Journal 2

Cumper A \& Lewis T, 'Empathy and Human Rights: The Case of Religious Dress' (2018) 18 Human Rights Law Review 1

Davies A, 'Achbita v G4S: Religious Equality Squeezed between Profit and Prejudice' (2017) European Law Blog, available at: <https://europeanlawblog.eu/2017/04/06/achbita-v-g4sreligious-equality-squeezed-between-profit-and-prejudice/> [Accessed $1^{\text {st }}$ March 2018] 
Hennette-Vauchez S, 'Case Comment: Equality and the Market: The Unhappy Fate of Religious Discrimination in Europe' (2017) 13 European Constitutional Law Review 4

Imhoff R. \& Recker J, 'Differentiating Islamophobia: Introducing a New Scale to Measure Islamoprejudice and Secular Islam Critique’ (2012) 33 Political Psychology 6

Laegaard S, 'Burqa Ban, Freedom of Religion and Living Together' (2015) 16 Human Rights Review 3

Lester A, 'Universality vs. Subsidiarity: A Reply’ (1998) 1 European Human Rights Law Review

Liu H, 'The Meaning of Religious Symbols after the Grand Chamber Judgment in Lautsi v Italy.' (2011) 6 Religion and Human Rights 3

McGoldrick D, 'Religion in the European Public Square and the European Public Life Crucifixes in the Classroom' 11 Human Rights Law Review 3

Nieuwenhuis A, 'Case Note: State and Religion, Schools and Scarves, An Analysis of the Margin of Appreciation as Used in the Case of Leyla Sahin v Turkey, Decision of 29 June 2004, Application Number 44774/98' 1 European Constitutional Law Review 3

Pearson M, 'Article 9 at a Crossroads: Interference Before and After Eweida' (2013) 13 Human Rights Law Review 3

Van der Schyff G \& Overbeeke A, 'Exercising Religious Freedoms in the Public Space: A Comparative and European Convention Analysis of General Burqa Bans' 7 European Constitutional Law Review 3

Vickers A, 'Achbita and Bougnaoui: One Step Forward and Two Step Back for Religious Diversity in the Workplace' (2017) 8 European Labour Law Journal 3

Weiler J, 'Case Comment: Je Suis Achbita' (2017) 28 European Journal of International Law 4 